\title{
Features and Construction of Cultural Identities for University EFL Learners in China
}

\author{
Gao Zhidong1,a
}

${ }^{1}$ School of Foreign Languages, Yan'an University, Yan'an City, Shaanxi Province, PR China, 716000

${ }^{\mathrm{a}}$ email

Keywords: Sociocultural Change; EFL Learners; Identity; Features; Construction

\begin{abstract}
EFL learners' cultural identities are influenced by and changed with frequency and degree of exposure to English language learning. Based on questionnaire and interview studies of 150 students from 3 universities, a CROSS model of features of their cultural identities was demonstrated, and a GLOBALIZATION model of construction of these identities was discussed.
\end{abstract}

\section{Introduction}

How people perceive their own and other cultures is of increasing importance in the age of globalization. It has been noticed that "change has encroached upon nearly every stable pattern of life - cultural values, religious beliefs, the structures and functions of sociocultural institutions including the family, and intergenerational relationship" (Kim \& Bhawuk, 2008). Globalization, foreign direct investment, the Internet, global education and entertaining programs are exposing China to unprecedented borderless and wireless global knowledge transfer, information sharing and cultural learning (Tony \& Guy, 2011). At the same time, Chinese institutions of higher learning are "actively courting foreign trained faculty", showing openness and willingness to adjust curriculum and making changes (Shenkar, 2005).Thus, the students exposing to these changes will inevitably experience relevant changes in their cultural identities.

The question shall be answered in the present study is what are the features of university students' cultural identities and how to help them to highly and effectively construct these identities.

\section{Effects of Globalization and Internationalization of Higher Education}

Internationalization of higher education has become the trend in the 21th century for higher education institutions. The major features of it include the resources of students, teachers, scientific research and development, attribution of alumni, textbooks and teaching materials, teaching and assessment, and administration (Wu Shulian, 2015). These have set a new and even higher demand on the services of higher education institutions.

It has been noted that the impact of China's modernization during the past thirty years on the modification of Chinese social and cultural behaviors is salient. However, one needs to consider the social and cultural changes at a deeper level-that of people's values. In the context of globalization, Chinese society has experienced this unique feature even in the most significant sociocultural changes. A constant reality of China has been its outstanding capability for keeping up with paradoxes throughout its history including the current period.

In the context of globalization, learning a second or foreign language turns out to be a necessity, and exposing to other culture(s) derives and results in simultaneous representations of identity changes. While learning a foreign language, the learners will acquire novel linguistic knowledge 
and skills, and promote their language competence. Meanwhile, the learners' cultural identity, e.g. attitudes and values, will eventually change.

At the surge of globalization and in the rapidly changing world, individuals are inevitably confronted with considerable challenges to their traditional values. When a growing number of Chinese students are seeking to study in higher education institutions and exposing to foreign language and cultures, it is necessary and important to see that they are not only seeking paths through education to themselves' and their family's prosperity, happiness and wellbeing, but also experiencing and balancing the conflict between modern western values presently exposed to them and their traditional values deeply rooted in Confucianism.

Cross-cultural study of traditional values has been conducted for many years. These studies proposed theories and models explaining changes of traditional values across different cultures. Yet cross-cultural studies of values have mostly focused on commonalities and differences in the content and structure of values, and have made relatively little effort to understand how values evolve in response to the sociocultural change occurring throughout the world. Various factors of values across cultures have been identified according to some research on the common structure of values. This line of research focused on cultural differences in value orientation, social and cultural changes that most Eastern societies are undergoing as a result of industrialization.

\section{Cultures and Resorting to Contrasting Models of Intellectual Processes}

Chinese culture and Western culture are often regarded as resorting to contrasting models of intellectual processes in many respects (Nisbett, 2003). As pointed out by Chen (2002) in attempting to discuss the transcending paradox from a "middle way" perspective, "there is no doubt that Chinese people see the world differently from westerners for two obvious reasons: the radically different nature of the Chinese script, and the isolation in which Chinese civilization developed". China's "open-door” policy started over 30 years ago and its increasing interactions with foreign cultures make cultural learning and cultural change realities of today's Chinese society.

Over the years, studies have suggested that sociocultural events like migration, industrialization, and higher education have brought on challenges to traditional values (Inglehart, 1990; Pan, et al, 1994), and that emphasis on differences in values between cultures may suggest possibilities for cultural clash.

Yet few of these studies have systematically investigated how traditional values rooted in such a particular cultural ideology as Confucianism have progressed in rapidly changing sociocultural contexts, and even less have simultaneously examined values of Chinese college students to understand the relationship between sociocultural conditions and traditional Confucian values.

\section{Theoretical Frame Works and Research Methodology}

Based on theories of sociolinguistics, social psychology, cross-cultural communications, and identity studies, and applying methods of literature, reflection and questionnaires, the present study examined 150 university students from Beijing, Xi'an and Yan'an. The purpose of this paper is to examine the sociocultural change, ad jointly represented in cultural contact and exposure to foreign languages, and traditional Confucian values among Chinese students. To be more particular, the changes of cultural identities which are one of the fundamental aspects of these socialcultural changes and values based on the college students' exposure to English language and western cultures and values will be hypothesized and discussed. 


\section{Features of “CROSS” Model of Cultural Identities}

The following were the major findings of the present study concerning features of cultural identities among the university EFL learners.

First, motivations for learning English were significantly influenced by social, cultural, and economic developments.

Secondly, changes of attitudes towards traditional Confucian values occurred in tune with the increasing exposure to English language and western cultures.

Thirdly, for the college students involved in the study, their identity styles, identity dimensions, and identity functions were indicated with significant differences.

Lastly, coexistence of dual cultural identities became the new normal for English learners at universities in China.

To summarize, a CROSS model of these features were proposed, and it required a corresponding solution to these issues.

A "CROSS" model of the features was proposed, with C standing for conflict between traditional Confucian values and western values, $\mathrm{R}$ standing for reflection on the new identity resulting from exposure to foreign language(s) and culture, O standing for operation of the newly formed identity, the first S standing for sensibility when confronting with the conflict of forming the new identity, and the last $S$ standing for solution explorer which indicated the students' awareness in attempting to explore and to find solutions to the issues of identity forming.

\section{Globalization Model of Cultural Identity Construction}

What was comparatively more significant of the present study was the "GLOBALIZATION" model proposed for comprehensive construction of cultural identities for university EFL learners.

Practically, the features of cultural identities found in the study basically reflected and revealed the reality when university students in China came across the confusion resulted from exposure to foreign culture and language learning. The ideas proposed in the present study for constructing new cultural identities were thought to be practice-oriented. The suggestions of global (G) perspective, thinking and mindset, language $(\mathrm{L})$ competence, occupational $(\mathrm{O})$ knowledge and skills, learners’ cultural and educational background (B) and experience, their ability and aspiration (A) for international communication, local (L) actions presented in realizing and forming steady, rational and effective identities, innovation competence (I), zest and zigzag (Z), tangram spirit and triangulation $(\mathrm{T})$ for intercultural communication, and national dignity $(\mathrm{N})$ for reservation and promotion of traditional Chinese culture and values.

\section{References}

[1] Chen, M. J. Transcending paradox: The “middle way” perspective[J]. Asia Pacific Journal of Management, 2002(19):179-199.

[2] Inglehart, R. (1990). Culture shift in advanced industrial society. Princeton[M], NJ: Princeton University Press.

[3] Kim, Y. Y., \& Bhawuk, D. P. S. Globalization and diversity: Contributions from intercultural research[J]. International Journal of Intercultural Relations, 2008(32): 301-304.

[4] Nisbett, R. (2003). The geography of thought: How Asians and Westerners think differently—and why[M]. London: Nicholas Brealey.

[5] Pan, Z., Chaffee, S., Chu, G., \& Ju, Y. (1994). To see ourselves: Comparing traditional Chinese and American cultural values[M]. Boulder, CO: Westview Press. 
[6] Shenkar, O. (2005). The Chinese century: The rising Chinese economy and its impact on the global economy, the balance of power, and your job[M]. Upper Saddle River, NJ: Wharton School Publishing.

[7] Tony Fanga, Guy Olivier Faure, Chinese communication characteristics: A Yin Yang perspective[J]. International Journal of Intercultural Relations, 2011 (35):320-333.

[8] Wu Shulian, Ranking List of China Universities and Colleges, http://edu.qq.com/a/20150616/031384.htm.

陕西省延安市宝塔区圣地路 580 号, 延安大学外国语学院, 高治东。邮编 716000。电话 13892118998 